\title{
Jet and ultrasonic nebuliser output: use of a new method for direct measurement of aerosol output
}

\author{
J H Dennis, S C Stenton, J R Beach, A J Avery, E H Walters, D J Hendrick
}

\begin{abstract}
Output from jet nebulisers is calibrated traditionally by weighing them before and after nebulisation, but the assumption that the weight difference is a close measure of aerosol generation could be invalidated by the concomitant process of evaporation. A method has been developed for measuring aerosol output directly by using a solute (fluoride) tracer and aerosol impaction, and this has been compared with the traditional weight loss method for two Wright, six Turbo, and four Micro-Cirrus jet nebulisers and two Microinhaler ultrasonic nebulisers. The weight loss method overestimated true aerosol output for all jet nebulisers. The mean aerosol content, expressed as a percentage of the total weight loss, varied from as little as $15 \%$ for the Wright jet nebulisers to $54 \%$ (range $45-61 \%$ ) for the Turbo and Micro-Cirrus jet nebulisers under the operating conditions used. In contrast, there was no discrepancy between weight loss and aerosol output for the ultrasonic nebulisers. These findings, along with evidence of both concentrating and cooling effects from jet nebulisation, confirm that total output from jet nebulisers contains two distinct fractions; vapour and aerosol. The vapour fraction, but not the aerosol fraction, was greatly influenced by reservoir temperature within the nebuliser; so the ratio of aerosol output to total weight loss varied considerably with temperature. It is concluded that weight loss is an inappropriate method of calibrating jet nebuliser aerosol output, and that this should be measured directly.
\end{abstract}

Jet nebulisers are widely used in respiratory medicine in preference to ultrasonic nebulisers because they are traditional, economical, and efficient in producing respirable aerosols. They are used therapeutically to deliver bronchodilators, antimicrobials, mucolytic drugs, and local anaesthetics to the airways and gas exchanging tissues. Diagnostically, they are used in inhalation provocation tests to deliver drugs, allergens, and industrial chemicals-for example, in the measurement of non-specific bronchial responsiveness and in the investigation of occupational or environmental causes of asthma and alveolitis. For diagnostic purposes precision of dose delivery, through accurate nebuliser calibration, is critical if threshold values and doseresponse relationships are to be defined.

The mechanism of jet nebulisation is well understood. ${ }^{1}$ Compressed air is forced through a narrow orifice within the nebuliser and negative pressure is created by the expanding jet, which draws liquid up a feeder tube by the Bernoulli effect. The liquid then enters the air stream and is broken up by air turbulence within the jet itself and by impaction on interior surfaces within the nebuliser. Baffle structures within the nebuliser filter all but a small proportion of respirable aerosols back to a common reservoir. The total mass of released aerosol defines the available dose of solute, and the size distribution dictates its potential deposition in the respiratory tract. ${ }^{23}$ The present investigation is primarily concerned with measurement of aerosol mass.

Nebuliser output is conveniently calibrated by weighing the nebuliser unit before and after activation. ${ }^{4-8}$ This assumes that no solvent is lost during nebulisation by the concomitant process of evaporation-an assumption known to be incorrect. ${ }^{19-15}$ To investigate the importance of this potential limitation to the weight loss method of calibration we have developed a method for direct measurement of aerosol output using a chemical (fluoride) tracer. We have compared this with the traditional method of calibration by weight loss in several types of jet nebuliser and one type of ultrasonic nebuliser. In addition, we have used this new technique to investigate the effect of reservoir temperature and air flow rate on jet nebuliser output.

\section{Methods}

NEBULISERS

Three types of jet nebuliser were chosen for study, two Wright (Aerosol Medicals Ltd, Colchester), four Micro-Cirrus (Intersurgical, Twickenham), and six Turbo (Medic Aid, Pagham) nebulisers. Two Microinhaler ultrasonic nebulisers (Vestric, Runcorn) were also examined. Measurements of weight loss and aerosol output were determined in parallel four to seven times.

\section{MEASUREMENT OF TOTAL OUTPUT BY}

GRAVIMETRIC ANALYSIS

Before and after each activation period, during which aerosol was collected as described below, jet nebulisers (the nebuliser itself, nebuliser reservoir, and fitted $\mathrm{T}$ piece) were disconnected and weighed on a Mettler analytical balance 
(model H6GD, Gallen Camp, Loughborough) to the nearest $0.01 \mathrm{mg}$. For measurement of weight loss from the Microinhaler ultrasonic nebuliser the reservoir container (a $20 \mathrm{ml}$ glass vial) was removed and weighed in a similar way. The time taken to weigh an individual nebuliser unit was about 30 seconds. From a separate study of repeatability of weighings it was found that the $95 \%$ confidence interval for the difference of a pair of weighings was $\pm 0.89 \mathrm{mg}^{16}$

MEASUREMENT OF AEROSOL OUTPUT BY FLUORIDE TRACER METHOD

Aerosol generation and preparation of solute

tracer

Fresh solutions of $1.00 \% \mathrm{w} / \mathrm{v}$ sodium fluoride (BDH Chemicals Ltd, Blyth) were prepared in distilled water $(10.0 \mathrm{~g} / \mathrm{l})$, and $5 \mathrm{ml}$ aliquots were placed in each nebuliser. Compressed air (British Oxygen Company medical grade) was driven through the Turbo and Micro-Cirrus nebulisers from a pressure of $20 \mathrm{lb} / \mathrm{in}^{2}(138$ $\mathrm{kPa}$ ), which resulted in a flow rate of $7.5 \mathrm{l} / \mathrm{min}$. For the Wright nebuliser a flow rate of $8.0 \mathrm{l} /$ min was used. A 2.00 second nebulisation through the Micro-Cirrus and Turbo nebulisers was directed by a locally designed, microprocessor controlled dosimeter. ${ }^{17}$ For the Wright jet nebulisers we used three minutes of continuous nebulisation. The ultrasonic nebulisers were manually activated in short bursts of $0 \cdot 5-5 \cdot 0$ seconds.

\section{Collection of aerosol output}

During activation of nebulisers ambient air was drawn at $15 \mathrm{l} / \mathrm{min}$ through a fitted $\mathrm{T}$ piece over the nebulisers by a modified (reversed flow) MiniNeb Compressor (Bard Ltd, Sunderland). This entrained and impacted aerosols on to a $25 \mathrm{~mm}$ Whatman glass fibre (GF/A) filter (BDH Chemicals Ltd) held within a metal cassette positioned $5 \mathrm{~cm}$ from the nebuliser head (fig 1). Aerosols from the ultrasonic nebulisers were similarly impacted on to 37

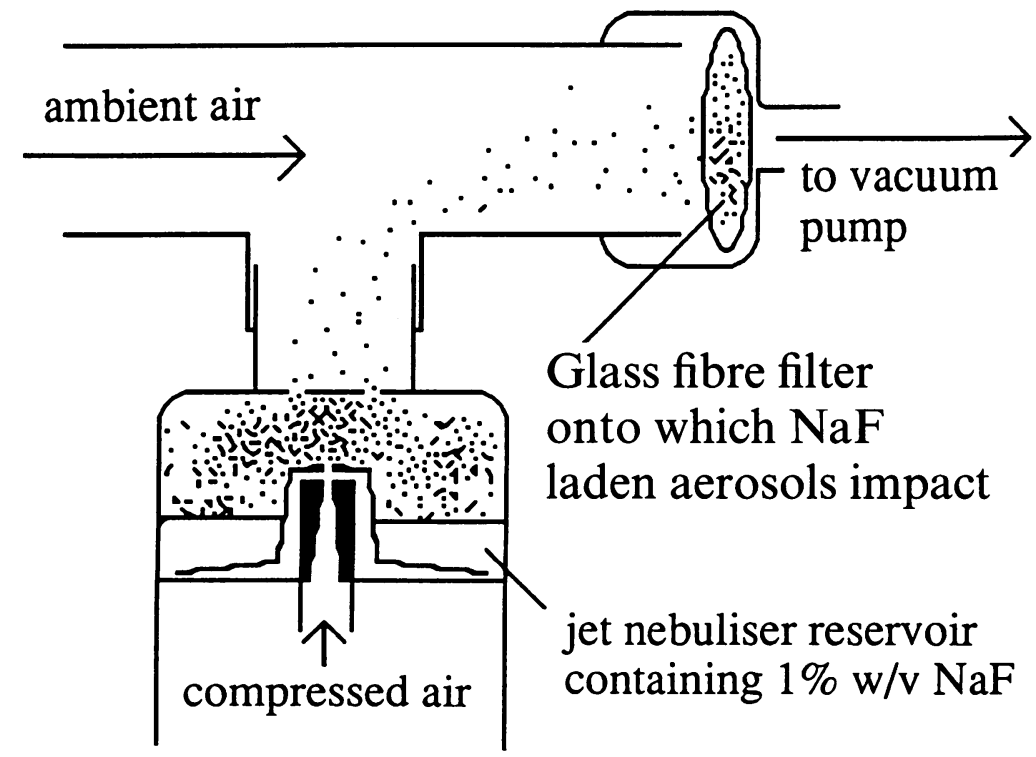

Figure 1 Schematic representation of method of aerosol collection. A glass fibre filter is held in front of the nebuliser. Fluoride laden aerosols emitted from the nebuliser during activation are entrained in an airstream and impact on the filter. The quantity of fluoride on the filter is subsequently desorbed and measured electrochemically. $\mathrm{mm} \mathrm{GF} / \mathrm{A}$ filters, through which air was drawn at $25 \mathrm{l} / \mathrm{min}$. A higher flow rate and larger filter were used for the ultrasonic nebulisers because the filter could not be positioned as close to the source of nebulisation. After aerosol collection GF/A filters were removed and stored for later analysis. For flow rates of $15 \mathrm{l} / \mathrm{min}$ and above and for aerosols having a mass median diameter of $0.3 \mu \mathrm{m}$ or more the collection efficiency of GF/A filters exceeds $99.9 \% .{ }^{18}$ When a second filter was placed in series we detected no aerosol breakthrough.

\section{Analysis of aerosol output}

Total ionic strength adjustment buffer (TISAB; BDH Chemicals Ltd) was prepared as a $50 \%$ solution in distilled water, and $20 \mathrm{ml}$ were added to each Whatman filter within 25 $\mathrm{ml}$ plastic Universal bottles. The bottles were then sealed and fluoride was allowed to desorb overnight. The recovery of fluoride from filters was complete $(>98 \%$ ) and no fluoride was detected in unused filters. Fluoride analysis followed well established protocols. ${ }^{19}$ Fluoride standards were prepared by microlitre injections of $5.0,10.0$, and $15.0 \mu \mathrm{l}$ of $1.00 \%$ sodium fluoride into $20 \mathrm{ml}$ aliquots of $50 \%$ TISAB buffer, resulting in $5.95 \mathrm{E}^{-5} \mathrm{M}, 1 \cdot 19 \mathrm{E}^{-4} \mathrm{M}$, and $1 \cdot 78 \mathrm{E}^{-4} \mathrm{M}$ fluoride solutions. Both standard and test solutions were equilibrated to $25^{\circ} \mathrm{C}$ in a water bath. Fluoride concentrations within the buffered solutions were then measured electrochemically with a fluoride specific ion electrode (Corning Ltd, Halstead) on a Corning $255 \mathrm{pH} /$ ion meter with a calomel reference electrode. This electrochemical system had a log-linear relation between concentration and activity (mV) from $10^{-1} \mathrm{M}$ to $10^{-6} \mathrm{M} \mathrm{F}$. All solutions were continually agitated during analysis with an electromagnetic stirrer. An internal two point calibration was established with the 5 and $15 \mu$ l fluoride standards and its accuracy was checked with the $10 \mu \mathrm{l}$ standard. The standard curve was used to quantify all test solutions and reported directly the microlitre quantity of aerosol fluoride impacted on and desorbed from the test filters. The error of fluoride determination was within $\pm 2 \%$. Given that the concentration of the chemical tracer used in this method is only $1 \%(\mathrm{w} / \mathrm{v}$ as sodium fluoride), the density of the solution is virtually unity, allowing direct comparison of weight loss and aerosol output-that is, $1 \mathrm{mg}=1 \mu \mathrm{l}$.

\section{CONCENTRATION AND TEMPERATURE CHANGES} WITHIN NEBULISER SOLUTIONS

For investigating the effect of jet nebulisation on reservoir concentration and temperature in a Wright jet nebuliser we used $5 \mathrm{ml}$ of $1.00 \%$ sodium fluoride solution and an air flow rate of $8.0 \mathrm{l} / \mathrm{min}$. Temperature was monitored with a thermocouple $\left( \pm 0 \cdot 1^{\circ} \mathrm{C}\right)$, which lay in the reservoir solution. At time 0 and at roughly three minute intervals the reservoir temperature was recorded and nebulisation was interrupted for 30 seconds so that three $10 \mu \mathrm{l}$ aliquots of the reservoir solution could be removed for fluoride analysis. A similar investigation was made with an ultrasonic nebuliser except that reservoir temperatures and concen- 
trations were measured before and after the period of nebulisation only.

EFFECT OF TEMPERATURE ON WEIGHT LOSS AND AEROSOL OUTPUT

The effect of temperature on jet nebuliser weight loss and aerosol output was investigated in a dosimeter driven Turbo nebuliser. Separate sodium fluoride solutions $(1.00 \%$, $5 \mathrm{ml}$ ) were warmed to $40^{\circ} \mathrm{C}$ or cooled to $5^{\circ} \mathrm{C}$ and allowed to equilibrate to ambient temperature $\left(21^{\circ} \mathrm{C}\right)$ for 15 minutes. Temperature was measured continuously with a thermocouple. At 0.5-2 minute intervals reservoir temperature was recorded and the nebuliser was activated for 2.0 seconds at a flow rate of $7.5 \mathrm{l} /$ min. Output was determined by both the weight loss and the fluoride tracer methods at each temperature point.

\section{EFFECT OF AIR FLOW RATE ON JET NEBULISER OUTPUT}

A Wright jet nebuliser was filled with fresh 5 $\mathrm{ml}$ solutions of $1.00 \%$ sodium fluoride and activated for periods of 20 seconds at flow rates of $3,5,7,9$, and $11 \mathrm{l} / \mathrm{min}$. Weight loss and aerosol outputs were determined in triplicate for each flow rate. In a similar but more prolonged experiment using an airflow rate of $4.5 \mathrm{l} / \mathrm{min}$ the nebuliser was activated until at least half of the reservoir solution $(10 \mathrm{ml}$ of $1.00 \%$ sodium fluoride) had dissipated; during this period any aerosol emitted was captured on a GF/A filter.

\section{Results}

MEASUREMENT OF NEBULISER OUTPUT

The mean weight loss from the nebulisers under the operating conditions used ranged from $356 \mathrm{mg}$ with a Wright nebuliser to $9.3 \mathrm{mg}$ with a Micro Cirrus nebuliser (table). Weight loss substantially overestimated aerosol output for all jet nebulisers. Mean aerosol output expressed as a proportion of total weight loss varied from as little as $15 \%$ for the Wright jet nebuliser to $54 \%$ (range $45-61 \%$ ) for Turbo and Micro-Cirrus jet nebulisers. No significant difference between total weight loss and aerosol output was noted for the ultrasonic nebulisers.

EFFECT OF NEBULISATION ON CONCENTRATION AND TEMPERATURE OF JET NEBULISER SOLUTIONS Activation of a Wright nebuliser for 35 minutes dissipated $3.6 \mathrm{ml}$ of the $5.0 \mathrm{ml}$ reservoir solution. The concentration of fluoride increased from $1.00 \%$ to $3.01 \%$ and the reservoir temperature fell from $22^{\circ} \mathrm{C}$ to $9^{\circ} \mathrm{C}$ (fig 2). Activation of the ultrasonic nebuliser for six minutes dissipated $4.0 \mathrm{ml}$ of an original $5.0 \mathrm{ml}$ solution but had no appreciable effect on the reservoir concentration of fluoride (before $1.00 \%$, after $1.01 \%$ ) or temperature (before $22^{\circ} \mathrm{C}$, after $\left.23^{\circ} \mathrm{C}\right)$.

\section{EFFECT OF RESERVOIR TEMPERATURE ON JET} NEBULISER OUTPUT

The total weight loss from the Turbo jet nebuliser increased substantially with the temperature of the reservoir solution (fig 3), weight loss approximately tripling over the temperature range $5-40^{\circ} \mathrm{C}$. Over the range $5-35^{\circ} \mathrm{C}$ the increase was approximately linear (intercept 9.5; slope 0.58; $\mathrm{F}_{1,24}=188, \mathrm{p}<0.0001$ ). By contrast, the change in aerosol output, though statistically significant (intercept $8 \cdot 8$, slope $0.083 ; F_{1,24}=114, p<0.001$ ), was only 1.3 fold over this temperature range, and negligible over the normal range of operating temperatures $\left(10-25^{\circ} \mathrm{C}\right)$.

\section{EFFECT OF AIR FLOW RATE ON JET NEBULISER} OUTPUT

Mean weight loss increased approximately linearly with airflow rate through a Wright nebuliser (fig 4). For aerosol output, however, there was a threshold flow rate, near $7 \mathrm{l} / \mathrm{min}$, below which aerosol output was negligible. At higher

Mean composition of nebuliser output for the different models

\begin{tabular}{|c|c|c|c|c|c|c|}
\hline & $\begin{array}{l}\text { Nebulisation } \\
\text { time }(s)\end{array}$ & $\begin{array}{l}\text { No of } \\
\text { deter- } \\
\text { minations }\end{array}$ & $\begin{array}{l}\text { Mean }(S D) \\
\text { aerosol } \\
\text { output }(A O) \\
(m g)\end{array}$ & $\begin{array}{l}\text { Mean (SD) } \\
\text { weight loss } \\
(W L) \\
(m g)\end{array}$ & $\begin{array}{l}\text { Mean vapour } \\
\text { content } \\
(W L-A O) \\
(m g)\end{array}$ & $\begin{array}{l}\text { Mean }(S D) \\
\text { aerosol fraction } \\
(A O / W L) \\
(\%)\end{array}$ \\
\hline \multicolumn{7}{|l|}{ JET NEBULISERS } \\
\hline $\begin{array}{l}\text { Wright } 1 \\
\text { Wright } 2\end{array}$ & $\begin{array}{l}180 \\
180\end{array}$ & $\begin{array}{l}6 \\
4\end{array}$ & $\begin{array}{l}52.0(4 \cdot 6) \\
48.0(5 \cdot 2)\end{array}$ & $\begin{array}{l}356.0(14 \cdot 2) \\
320.0(15.9)\end{array}$ & $\begin{array}{l}306 \cdot 0 \\
272 \cdot 0\end{array}$ & $\begin{array}{l}14.6(1.0) \\
14.3(1.0)\end{array}$ \\
\hline $\begin{array}{l}\text { Turbo } 1 \\
\text { Turbo } 2 \\
\text { Turbo } 3 \\
\text { Turbo } 4 \\
\text { Turbo } 5 \\
\text { Turbo } 6\end{array}$ & $\begin{array}{l}2.00 \\
2.00 \\
2 \cdot 00 \\
2 \cdot 00 \\
2 \cdot 00 \\
2 \cdot 00\end{array}$ & $\begin{array}{l}5 \\
5 \\
5 \\
5 \\
5 \\
5\end{array}$ & $\begin{array}{r}6.4(0.2) \\
7.4(0.1) \\
10 \cdot 1(0.2) \\
11.4(0.3) \\
11.8(0.3) \\
12.0(0.6)\end{array}$ & $\begin{array}{l}14 \cdot 2(0 \cdot 6) \\
14 \cdot 4(1 \cdot 0) \\
18 \cdot 7(0 \cdot 7) \\
20 \cdot 1(1 \cdot 2) \\
20 \cdot 5(1 \cdot 1) \\
21 \cdot 2(0 \cdot 8)\end{array}$ & $\begin{array}{l}7 \cdot 8 \\
7 \cdot 0 \\
8 \cdot 6 \\
8 \cdot 7 \\
8 \cdot 7 \\
9 \cdot 2\end{array}$ & $\begin{array}{l}45.0(1.9) \\
51.2(3.9) \\
54.0(2.4) \\
56.8(3.1) \\
57.7(3.9) \\
56.4(5.5)\end{array}$ \\
\hline \multirow[t]{3}{*}{$\begin{array}{l}\text { Micro-Cirrus } 1 \\
\text { Micro-Cirrus } 2 \\
\text { Micro-Cirrus } 3 \\
\text { Micro-Cirrus } 4\end{array}$} & $\begin{array}{l}2 \cdot 00 \\
2 \cdot 00 \\
2 \cdot 00 \\
2 \cdot 00\end{array}$ & $\begin{array}{l}4 \\
4 \\
4 \\
4\end{array}$ & $\begin{array}{l}5 \cdot 1(0.3) \\
5.6(0 \cdot 1) \\
6 \cdot 2(0 \cdot 2) \\
6.9(0 \cdot 2)\end{array}$ & $\begin{array}{r}9.3(0.5) \\
11.0(0.4) \\
11.7(0.5) \\
11.4(0.3)\end{array}$ & $\begin{array}{l}4 \cdot 2 \\
5 \cdot 4 \\
5 \cdot 5 \\
4 \cdot 5\end{array}$ & $\begin{array}{l}54 \cdot 2(1 \cdot 7) \\
50 \cdot 8(2 \cdot 2) \\
53 \cdot 0(2 \cdot 6) \\
61 \cdot 2(2 \cdot 9)\end{array}$ \\
\hline & \multirow{2}{*}{$\begin{array}{l}\text { Nebulisation } \\
\text { time } \\
(s, \text { range })\end{array}$} & \multirow{2}{*}{$\begin{array}{l}\text { No of } \\
\text { deter- } \\
\text { minations }\end{array}$} & \multirow{2}{*}{$\begin{array}{l}\text { Aerosol } \\
\text { output } \\
\text { (mg, range) }\end{array}$} & \multirow{2}{*}{$\begin{array}{l}\text { Weight } \\
\text { loss } \\
\text { (mg, range) }\end{array}$} & \multicolumn{2}{|l|}{ Aerosol fraction } \\
\hline & & & & & $\overline{\text { (mg, range })}$ & $(\%$, mean $(S D))$ \\
\hline \multicolumn{7}{|c|}{ ULTRASONIC NEBULISERS * } \\
\hline $\begin{array}{l}\text { Microinhaler } 1 \\
\text { Microinhaler } 2\end{array}$ & $\begin{array}{l}0.5-5 \\
0.5-5\end{array}$ & $\begin{array}{l}5 \\
7\end{array}$ & $\begin{array}{c}8 \cdot 66-123 \\
18 \cdot 0-82 \cdot 2\end{array}$ & $\begin{array}{r}9 \cdot 4-115 \cdot 0 \\
16 \cdot 5-85 \cdot 0\end{array}$ & $\begin{array}{l}84 \cdot 9-107 \\
93 \cdot 9-109\end{array}$ & $\begin{array}{l}97 \cdot 5(9 \cdot 2) \\
99 \cdot 8(5 \cdot 1)\end{array}$ \\
\hline
\end{tabular}

^Ultrasonic nebulisation time was controlled by a manual trigger and ranged from about 0.5 to 5 seconds. 


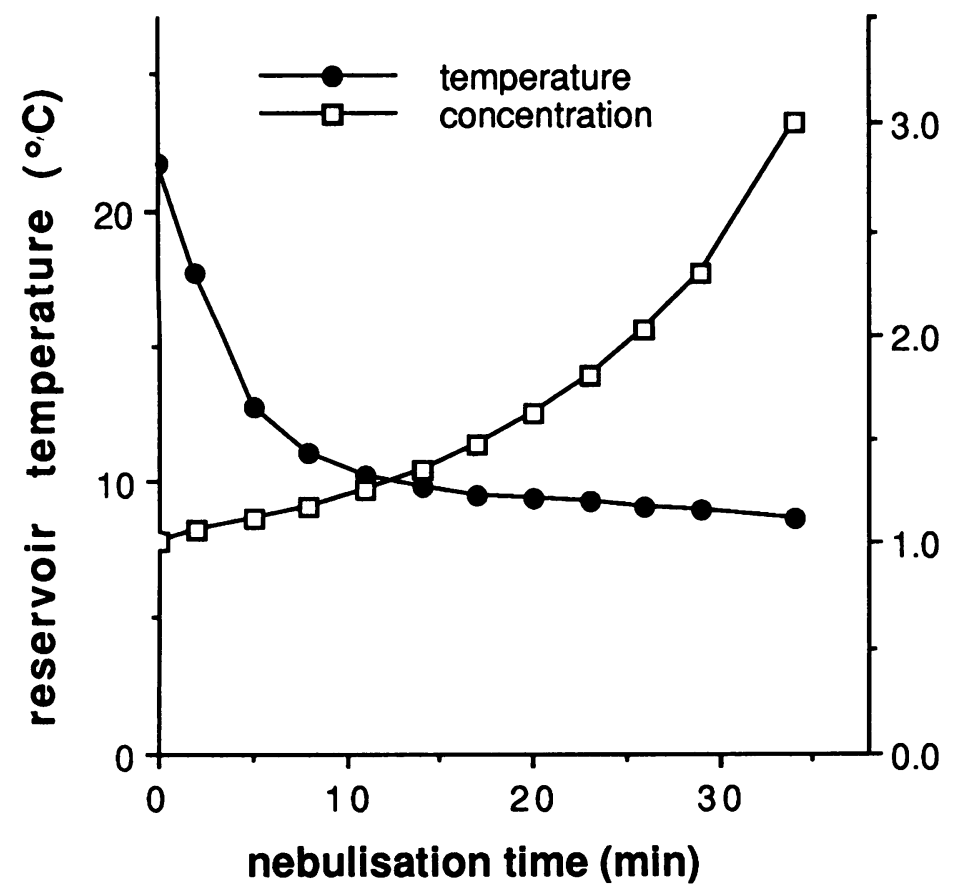

Figure 2 Effect of nebulisation on temperature $\left({ }^{\circ} \mathrm{C}\right)$ and concentration $(\% \mathrm{NaF})$ of the reservoir solution of a Wright jet nebuliser; $4 \mathrm{ml}$ of an original $5 \mathrm{ml}$ solution was nebulised over 35 minutes at a flow rate of $8.0 \mathrm{l} / \mathrm{min}$.

flow rates aerosol output increased substantially.

With an air flow rate of $4.5 \mathrm{l} / \mathrm{min} 155 \mathrm{~min}$ utes' activation reduced an initial $10.0376 \mathrm{ml}$ of $1.00 \%$ sodium fluoride solution to $4.4045 \mathrm{ml}$ in the Wright nebuliser. The reservoir sodium fluoride concentration increased to $2 \cdot 29 \%$, implying that essentially all the original sodium fluoride solute was still present in the reservoir (calculated initial content $=10.0 \mathrm{mg} / \mathrm{ml} \times$ $10.0376 \mathrm{ml}=100.4 \mathrm{mg}$; calculated final con-

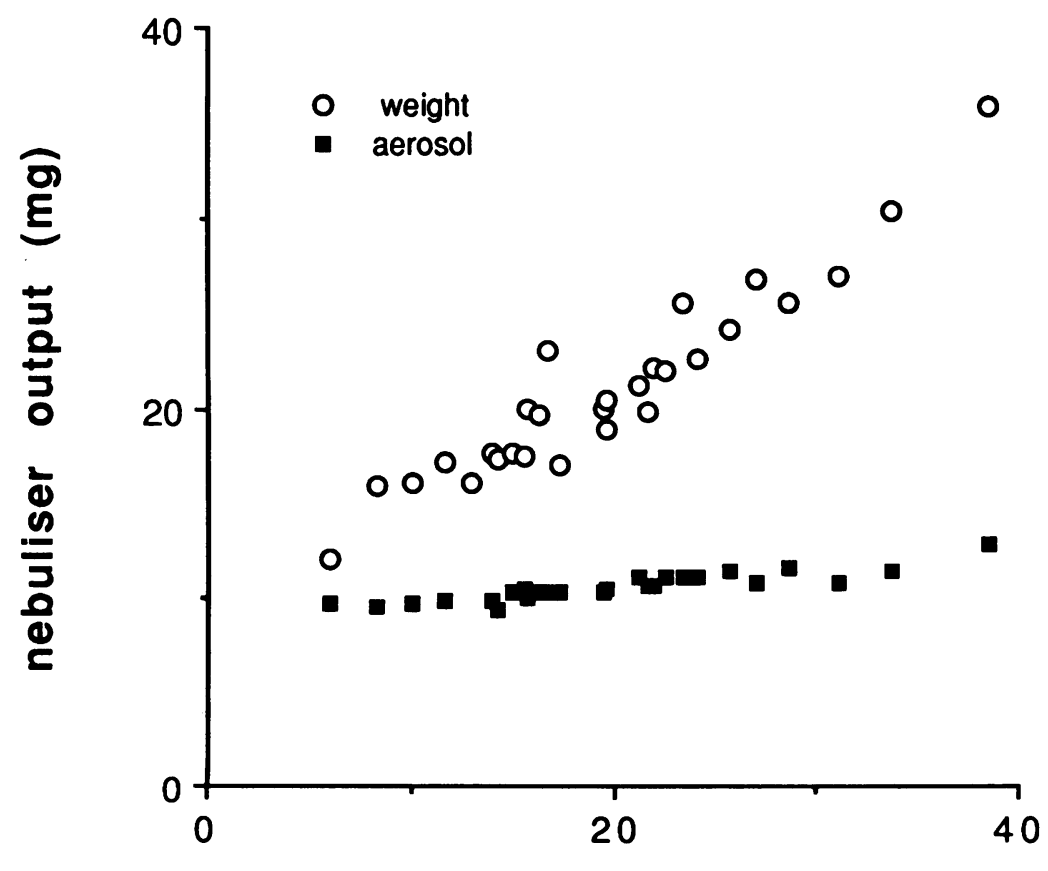

\section{reservoir temperature (C)}

Figure 3 Effect of reservoir temperature $\left({ }^{\circ} \mathrm{C}\right.$ ) on weight ( $\mathrm{mg}$ ) and aerosol ( $\mathrm{mg}$ ) output from a Turbo jet nebuliser. Temperature within the reservoir solution was monitored with a thermocouple. At selected intervals the nebuliser was activated for 2.00 seconds and measurements of weight loss and aerosol output were made.

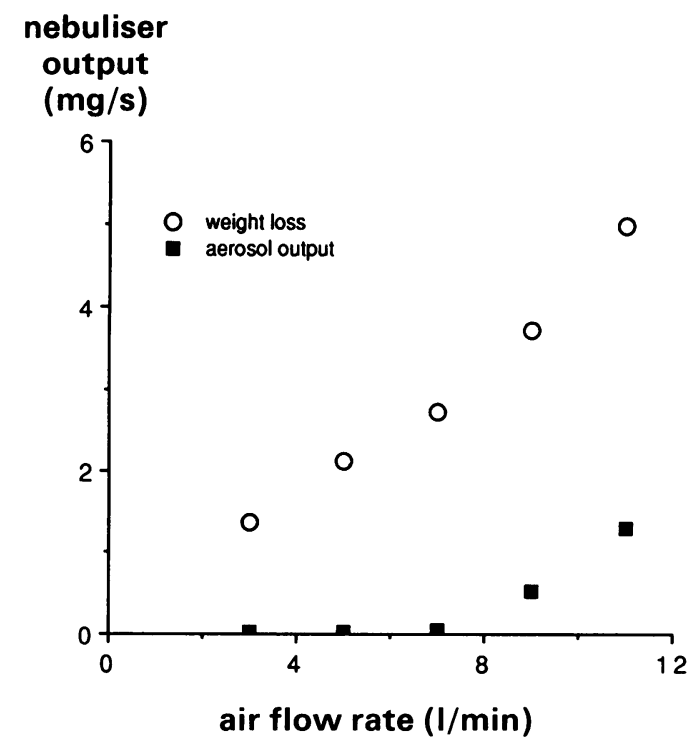

Figure 4 Effect of air flow rate (l/min) on rate of weight loss $(\mathrm{mg} / \mathrm{s})$ and aerosol output $(\mathrm{mg} / \mathrm{s})$ from a Wright jet nebuliser. Simultaneous measurements of weight loss and aerosol output over 20 second activation periods at flow rates of $3,6,9$, and $11 \mathrm{l} / \mathrm{min}$ were made in triplicate, from which mean values were calculated.

tent $=22.9 \mathrm{mg} / \mathrm{ml} \times 4.4045 \mathrm{ml}=100.9 \mathrm{mg}$ ). In parallel, only $0.292 \mathrm{mg}$ sodium fluoride was recovered as aerosol from the GF/A filter, which corresponds to less than $0.3 \%$ of the available solute.

\section{Discussion}

It is widely recognised that solutions in the reservoir of jet nebulisers concentrate and cool during use owing to evaporation of solvent, ${ }^{9-15}$ and we have found these effects in the reservoir solution of a Wright jet nebuliser. The corollary-that the weight loss overestimates the amount of solute nebulised-has not been fully investigated. This could exert an important confounding influence when jet nebulisers calibrated by weight loss are used to determine threshold levels and dose-response relationships from inhalation provocation tests.

Evaporation of solvent would not be expected from ultrasonic nebulisation and we detected neither concentrating nor cooling effects within ultrasonic nebuliser reservoirs. Nor did we find differences between aerosol output measured by the fluoride tracer method and weight loss. This close agreement validates the fluoride tracer method as a means of collecting and measuring true aerosol output. The principles of using chemical tracers and aerosol impaction have been successfully applied in similar systems. ${ }^{20}{ }^{21} \mathrm{By}$ contrast, there were substantial differences between total weight loss and aerosol output for all the jet nebulisers tested, total weight loss being as much as six times aerosol output in the case of the Wright nebuliser.

These results, supported by the findings on concentration and cooling effects, suggest that the process of jet nebulisation releases appreciable amounts of water vapour. On entering the nebuliser compressed air is almost completely dry. Within the high velocity air turbulence of the nebuliser jet, air may be 
expected to become saturated with water vapour. This alone did not fully account for all the differences observed between total weight loss and aerosol output. Compressed air driven through the Micro-Cirrus and Turbo jet nebulisers from our dosimeter per $2 \cdot 0$ second nebulisation acquired a mean volume of $250 \mathrm{ml}$ when expanded to atmospheric pressure and a mean temperature of $16^{\circ} \mathrm{C}$. Under these conditions it could theoretically absorb some $4.8 \mu \mathrm{l}$ of water vapour before saturation occurs (psychometric chart). Whereas this agrees closely with the mean vapour loss measured from the Micro-Cirrus jet nebuliser of 4.9 (range 4.25.5) $\mu$, higher vapour losses were noted from the Turbo nebuliser (mean $8 \cdot 3$, range $7 \cdot 0-9 \cdot 2$ $\mu \mathrm{l})$. These may be attributed to the Turbo nebuliser design, which causes additional losses to ambient air drawn through the nebuliser during activation.

The temperature of the reservoir solution strongly influenced the amount of weight loss but not aerosol output, implying that temperature exerted a major effect on vapour generation. The weak but significant effect of reservoir temperature on aerosol output is likely to be due to temperature dependent changes in surface tension and viscosity. Because jet nebuliser temperature decreases during nebulisation the relation between weight loss and aerosol output will vary during use. This means that measurements of weight loss cannot readily be adjusted to provide an accurate estimate of aerosol output.

Like other investigators we found that weight loss from the Wright jet nebuliser was directly related to airflow rate. ${ }^{22}{ }^{23}$ Aerosol output, however, showed no relation to air flow rate until a threshold flow around $7 \mathrm{1} / \mathrm{min}$ was reached. That this threshold flow rate exists was confirmed by the prolonged use of the Wright nebuliser at a flow rate of $4.51 / \mathrm{min}$. From this we measured a negligible aerosol output by the fluoride tracer method, and recovered essentially all the original solute in the concentrated solution at the end of nebulisation.

Our findings reinforce recent observations of other investigators. O'Callagan et al collected the output of nebulised sodium cromoglycate from three brands of jet nebuliser in a multistage liquid impinger and compared the aerosol content as assayed by spectrophotometric means with the observed weight loss. ${ }^{14}$ They concluded that drug output calculated from weight loss may result in overestimation of the true drug output by as much as $50 \%$. Cockcroft et al measured sodium concentration changes in saline solutions of Wright jet nebuliser reservoirs before and after nebulisation, and calculated that aerosol output was about a quarter of that predicted by weight loss. ${ }^{15}$

We conclude that use of the gravimetric method to determine aerosol output from jet (but not ultrasonic) nebulisers is inappropriate, and that direct measurement (by the fluoride tracer method, for example) should be used.

JHD was supported in part by the Asthma Research Council and JRB by the Newcastle Health Authority Research Committee.

1 Mercer TT. Production and characterisation of aerosols. Arch Intern Med 1973;131:39-50.

2 Tillery MI, Wood GO, Ettinger HJ. Generation and characterisation of aerosols and vapours for inhalation experiments. Environ Health Perspec 1976;16:25-40.

3 Clay MM, Pavia D, Newman SP, Clarke SW. Factors influencing the size distribution of aerosols from jet nebulisers. Thorax 1983;38:755-9.

4 Cockroft DW, Killian DN, Mellon JJA, Hargreave FE. Bronchial reactivity to inhaled histamine: a method and clinical survey. Clin Allergy 1977;7:235-43.

5 Nieminen MM, Holli H, Lahdensuo A, Muittari A, Karvonen J. Aerosol deposition in automatic dosimeter nebulization. Eur J Respir Dis 1987;71:145-52.

6 Newman SP, Pellow PGD, Clarke SW. In vitro comparison of DeVilbiss jet and ultrasonic nebulizers. Chest 1987; 92:991-4.

7 Tsanakas JN, Wilson AJ, Boon AW. Evaluation of nebulisers for bronchial challenge tests. Arch Dis Child 1987;62:506-8.

8 Kongerud J, Soyseth V, Johansen B. Room temperature influences output from the Wright jet nebulizer. Eur Respir J 1989;2:681-4.

9 Wright BM. A new nebuliser. Lancet 1958;ii:24-5

10 Clay MM, Pavia D, Newman SP, Lennard-Jones T, Clarke $\mathrm{SW}$. Assessment of jet nebulisers for lung aerosol therapy. Lancet 1983;ii:592-4.

11 Wood JA, Wilson RSE, Bray C. Changes in salbutamol concentration in the reservoir solution of a jet nebulizer. Br J Dis Chest 1986;80:164-9.

12 Clay MM, Clarke SW. Wastage of drug from nebulisers: a review. JR Soc Med 1987;80:38-9.

13 Schoni MH, Kraemer R. Osmolality changes in nebulizer solutions. Eur Respir J 1989;2:887-92.

14 O'Callaghan C, Clarke AR, Milner AD. Inaccurate calculation of drug output from nebulisers. Eur J Pediatr 1989; 148:473-4.

15 Cockroft DW, Hurst TS, Gore BP. Importance of evaporative water losses during standardized nebulized inhalation provocation tests. Chest 1989;96:505-8.

16 Bland MS, Altman DG. Statistical methods for assessing agreement between two methods of clinical measurement. Lancet 1986; i:307-10.

17 Connolly MJ, Avery AJ, Walters EH, Hendrick DJ. The relationship between bronchial responsiveness to methacholine and bronchial responsiveness to histamine in asthmatic subjects. Pulmon Pharm 1988;1:53-8.

18 Cotes JC, Steel J. Environmental monitoring. Work-related lung disorders. Oxford: Blackwell, 1987:23-48.

19 Crosby NT, Dennis ALM, Stevens JG. An evaluation of some methods for the determination of fluoride in potable waters and other aqueous solutions. Analyst 1968;93: 643-52.

20 Donna E, Danta I, Kim CS, Waner A. Relationship between deposition of and responsiveness to inhaled methacholine in normal and asymptomatic subjects. $J$ Allergy Clin Immunol 1989;83:456-61.

21 Kim CS, Lewars GG, Eldridge MA, Sackner MA. Deposition of aerosol particles in a straight tube with an abrup obstruction. J Aerosol Sci 1984;15:167-76.

22 Ryan G, Dolovich MB, Obminski G, et al. Standardization of inhalation provocation tests: influence of nebulizer output, particle size, and method of inhalation. $J$ Allergy Clin Immunol 1981;67:156-61.

23 Hickey AJ, Byron PR. Effect of solution flow rate on the output of two modified commercially available jet nebulizers. $J$ Pharm Sci 1987;76:338-40. 